\title{
Queer Belfast during the First World War: masculinity and same-sex desire in the Irish city
}

\author{
Tom Hulme* \\ Queen's University Belfast
}

\begin{abstract}
A B S T R A C T. Queer history is still in its infancy in Ireland, with political approaches and the more recent past, and the gay rights movement particularly, providing the primary focus so far. This article takes a different approach by investigating the everyday experiences, identities and policing of men who had sex with men in the early twentieth century. Using two extraordinary case studies from Belfast during the First World War, I explore different lives - from youth to adulthood, sexual encounter to arrest, and trial to life afterwards. I argue that queer culture in Belfast shared aspects with other western metropolises, particularly in terms of urban cruising, payment for sex and relationships structured by class. Public responses too, from newspaper to courtroom, were articulated through transnational formulations of respectability and masculinity. At the same time, however, Belfast's queer men were shaped by their movement within a peculiarly Irish network of places, both in and beyond the country's borders. Religious and political structures specific to Ulster also affected how such men fared in the legal system and in their lives following their trials. By detailing both the similarities yet divergences of queer experience in Belfast, I thus aim to raise a new agenda for studying male sexuality in the north of Ireland.
\end{abstract}

$I^{\prime}$

$\mathrm{n}$ Ireland, the study of the history of same-sex desire is comparatively young, with the recent past providing the primary focus so far. ${ }^{1}$ Investigations of the period before the advent of the gay rights movement are rare, and have often been more about politics than experiences. ${ }^{2}$ Particularly notable in this sense is

* School of History, Anthropology, Philosophy and Politics, Queen's University Belfast, t.hulme@qub.ac.uk

${ }^{1}$ See Orla Egan, Queer republic of Cork: Cork's lesbian, gay, bisexual and transgender communities, 1970s-1990s (Cork, 2016); Patrick McDonagh, "'Homosexuals are revolting" - gay and lesbian activism in the Republic of Ireland, 1970s-1990s' in Studi irlandesi, vii (2017), pp 65-91; idem, 'Abortion, gay rights, and the National Gay Federation in Ireland, 1982-1983' in Journal of the History of Sexuality, xxix, no. 1 (2020), pp 1-27; idem, “"Homosexuality is not a problem - it doesn't do you any harm and can be lots of fun": students and gay rights activism in Irish universities, 1970s1980s' in Irish Economic and Social History, xlvi (2019), pp 111-41; Kieran Rose, Diverse communities: the evolution of lesbian and gay politics in Ireland (Cork, 1994); and Chrystel Hug, The politics of sexual morality in Ireland (London, 1998), pp 201-40.

${ }^{2}$ For exceptions, see Diarmaid Ferriter, Occasions of sin: sex and society in modern Ireland (London, 2009), which delves into the early twentieth century, though mostly as a narrative of court cases in Dublin; Brian Lacey, Terrible queer creatures: homosexuality in Irish history (Dublin, 2009), which has chapters on two queer Dublin Castle scandals 
the attention given to Roger Casement, the diplomat-turned-revolutionary who was executed by the British government for treason in 1916. He recorded his sexual cruising in the so-called black diaries, extracts of which were circulated by the state to discourage public support for a reprieve. It is telling that many historians have been more preoccupied with defending or denying the authenticity of these remarkable primary sources, or tracing the afterlife of the Casement controversy, than using their contents to reconstruct homosexual interactions. As Kathryn Conrad has put it, '[f]or Irish nationalists to accept that Casement was an "Irish patriot" - and particularly, to claim him as a martyr - required that his homosexuality be pushed back into the closet or denied'; to some degree, this battle is still ongoing. ${ }^{3}$ For Belfast specifically, the quest for legalisation and acceptance against the backdrop of the Troubles (1968-98) has been the motivating narrative for queer history. ${ }^{4}$ Work on Edward de Cobain, the M.P. for East Belfast in the 1880s, is one of two exceptions. After being accused of 'gross indecency' with young men in the

(1884 and 1907); and Averill Earls, 'Unnatural offenses of English import: the political association of Englishness and same-sex desire in nineteenth-century Irish nationalist media' in Journal of the History of Sexuality, xxviii, no. 3 (2019), pp 396-424. Earls's other work on Dublin, 'Queering Dublin: same-sex desire and masculinities in Ireland, 1884-1964' (Ph.D. thesis, University at Buffalo, 2016) and 'Solicitor Brown and his boy: love, sex, and scandal in twentieth-century Ireland' in Historical Reflections/Réflexions Historiques, xlvi, no. 1 (2020), pp 79-94, is the first to give sustained investigation into the actual experiences of queer Irish men.

${ }^{3}$ Kathryn Conrad, 'Queer treasons: homosexuality and Irish national identity' in Cultural Studies, xv, no. 1 (2001), p. 129; Kevin Grant, 'Bones of contention: the repatriation of the remains of Roger Casement' in Journal of British Studies, xli, no. 3 (2002), pp 329-53; and Lucy McDiarmid, The Irish art of controversy (Dublin, 2005), pp 167-210 are particularly useful for understanding the politics of Casement's memory in the twentieth century and the development of the authenticity debate. McDiarmid notes that 'the popular emotions exacerbated by and expressed through Casement controversies' (p. 210) no longer exist; terse missives, however, have continued. See, from a sceptic, Angus Mitchell, 'Phases of a dishonourable phantasy' in Field Day Review, viii (2012), pp 84-125, and, in reply, Jeffrey Dudgeon, 'Casement wars' in Dublin Review of Books (Apr. 2013). Jeffrey Dudgeon, Roger Casement: the Black Diaries - with a study of his background, sexuality and Irish political life (Belfast, 2002) and Brian Lewis, 'The queer life and afterlife of Roger Casement' in Journal of the History of Sexuality, xiv, no. 4 (2005), pp 368-74, give the closest attention to his sexuality. There are also briefer speculative readings of the sexuality of other Irish nationalists - such as Francis Joseph Bigger, Patrick Pearse, Cathal O'Byrne and Michael Collins - but they lack both the 'smoking gun' evidence and the rancour that characterises the Casement controversy. See, for example: Richard Kirkland, Cathal O'Byrne and the northern revival in Ireland, 1890-1960 (Liverpool, 2006), pp 97, 2235; Joost Augusteijn, Patrick Pearse: the making of a revolutionary (Basingstoke, 2010), pp 56-62; and Anne Dolan and William Murphy Michael Collins: the man and the revolution (Dublin, 2018), pp 319-26.

${ }^{4}$ See Marian Duggan, Queering conflict: examining lesbian and gay experiences of homophobia in Northern Ireland (Farnham, 2012), which concentrates on the Troubles to the present; Sean Brady, "'Save Ulster from sodomy!" Homosexuality in Northern Ireland after 1967' in Cultural and Social History (forthcoming); and Rachel Wallace, 'Communicating gay life and liberation in Belfast and Boston in the 1970s' (Ph.D. thesis, Queen's University Belfast, 2018). Ferriter, Occasions of sin, has a brief discussion of Casement that references Belfast (p. 67), but analysis of the city is limited to the fight for law reform in the 1970s and after (pp 475-83). 
city in 1891, he fled the country and was expelled from the House of Commons; in 1893 he finally returned to be convicted, spelling the end of his political career. Doubt has been cast on de Cobain's guilt, if notably without the same degree of defensive enthusiasm drummed up for the much-romanticised Casement, but only the political ramifications of shame, rather than his sexual practices specifically, have been analysed. ${ }^{5}$ The obstinately non-political Forrest Reid, Ulster's most famous early twentieth-century author, is the other exception. Work on Reid arguably reflects the more prominent role that literary scholars have taken in revealing queer undertones in a society that could not discuss such topics openly. ${ }^{6}$

Often left behind by both political and literary approaches are the men who actually had sex with each other, and how specific geographies and cultures - nationalist, unionist or neither - affected individual experiences and understandings of 'queerness'. Such a lack of a 'history from below' is arguably due to certain lags in Irish historical studies. The first of these relates to gender as a theoretical framework. In 2013, Sean Brady maintained that masculinities 'barely exist in the historiography of Ireland, and of Northern Ireland in particular', 7 a point reaffirmed by Catriona Kennedy three years later. ${ }^{8}$ Rebecca Anne Barr et al., in a recent landmark intervention, reasoned that this 'relative lack of attention' is both a 'side-effect of the politically necessary focus on women's histories' and 'reflective of a persistent conservatism still reluctant to recognise the gendering of men'. The history of Ireland, they maintain, has tended toward a 'political narrative' that relies on 'a deeply traditional empirical methodology'. ' In the last few years, however, and relevant for the period and place under consideration here, there have been moves toward a more nuanced understanding of masculinity in Irish history. Work by Jane McGaughey and Aidan Beatty, for example, has shown how unionist and nationalist identities intersected with powerful understandings of 'manliness'

${ }^{5} \mathrm{Cal}$ Murgu, “'Innocence is as innocence does”: Anglo-Irish politics, masculinity and the de Cobain gross indecency scandal of 1891-3' in Gender and History, xxix, no. 2 (2017), pp 309-28. Nicola Morris has suggested a political conspiracy: 'Was Orangeman Edward de Cobain jailed for a crime he didn't commit?', B.B.C. (16 Sept. 2011) (https://www.bbc.co. uk/news/uk-northern-ireland-14941512) (30 June 2021).

${ }^{6}$ Rebecca Anne Barr, 'Forrest Reid's queer Ulster pastoral' in Rebecca Anne Barr, Sarah-Anne Buckley and Laura Kelly (eds), Engendering Ireland: new reflections on modern history and literature (Newcastle, 2015), pp 196-216, looks at Reid's 'obsessive fixation on the beauty and significance of male boyhood', though Graham Walker, 'Belfast, boys and books: the friendship between Forrest Reid and Knox Cunningham' in Irish Review, xxxv (2007), pp 132-43, focuses on his life of letters. For queer literary approaches to Ireland more broadly, see, as examples, Joseph Valente (ed.), Quare Joyce (Ann Arbor, MI, 1998); idem, The myth of manliness in Irish national culture, 1880-1922 (Urbana, IL, 2011); and Eibhear Walshe, Oscar's shadow: Wilde, homosexuality and modern Ireland (Cork, 2011).

${ }^{7}$ Sean Brady, 'Why examine men, masculinities and religion in Northern Ireland?' in Lucy Delap and Sue Morgan (eds), Men, masculinities and religious change in twentiethcentury Britain (Basingstoke, 2013), p. 218.

${ }^{8}$ Catriona Kennedy, 'Women and gender in modern Ireland' in Richard Bourke and Ian McBride (eds), The Princeton history of modern Ireland (Princeton, 2016), p. 361. There is extensive work on women and gender in modern Ireland, and a sustained interest in sexuality in terms of the control of women's bodies. For Belfast in particular, see Leanne McCormick, Regulating sexuality: women in twentieth-century Northern Ireland (Manchester, 2011).

9 Rebecca Anne Barr, Sean Brady and Jane McGaughey, 'Introduction' in idem (eds), Ireland and masculinities in history (Basingstoke, 2019), pp 3-5. 
during the Home Rule Crisis and Irish Revolution. ${ }^{10}$ In another way, the lack of work on Irish queerness reflects the conceptual narrowness of urban approaches, which have been fundamental to queer studies elsewhere. In 2018, Olwen Purdue and Jonathan Jeffrey Wright remarked that '[m]uch work remains to be done' to understand Irish cities as not just the containers of social and political change but 'spaces' that, among other things, 'shape the behaviour' and 'power relationships' of those that live in them. ${ }^{11}$ Even more recently, Erika Hanna and Richard Butler also argued, in an otherwise positive piece, that historians of urban Ireland have been 'more at ease in deeply empirical local or national studies than in negotiating unfamiliar approaches, concepts or typologies'. Two avenues for future inquiry they identify for twentieth century research would be particularly useful for queering Irish history: work that 'adequately theorizes' the 'distinctive culture[s]' of urbanity and makes 'sense of the micro-geographies of social change'; and 'a turn to the transnational' to understand 'cities and towns' as 'sites of movement' that drew in 'rural populations' and worked as 'nodal points' for migration, leading to the creation of 'distinctive Irish communities' all over the globe. ${ }^{12}$

In this article, I investigate men who had sex with men in wartime Belfast to explore how these recent developments in gender and urban history could productively intermesh with the history of sexuality. I use the extraordinary cases of two ordinary men. Edgar John Milligen, twenty-nine years old and from just outside Lisburn, County Antrim, was arrested in November 1916 for committing 'acts of gross indecency with another male person'. The son of a wealthy Scottish-born Ulster industrialist, Milligen had allegedly been meeting adolescent newsboys on the streets of Belfast and paying them for sex in ice cream parlours, hotels and his country house in the village of Lambeg. ${ }^{13}$ About a year later, Vincent Cassidy, a twenty-five-year-old from Armagh, was arrested for a similar crime. Not long back in Ulster after a two-year stay in the United States, he had been living in a hotel in the centre of Belfast and holding all-male parties in his rooms; soldiers and civilians alike danced, drank cocktails and shared the one bed. ${ }^{14}$ Witness statements from some of the men involved are held in the Public Record Office of Northern Ireland. As found by historians of other places beyond London, notably Wales and northern England, assizes material for same-sex offences rarely survives

10 Jane McGaughey, Ulster's men: Protestant unionist masculinities and militarization in the north of Ireland, 1912-1923 (Montreal, 2012); Aidan Beatty, Masculinity and power in Irish nationalism, 1884-1938 (London, 2016). Similarly, see John Wilson Foster, 'Corrigbly plural? Masculinity in life and literature' and Dale Montgomery, “They were the men who licked the IRA until they squealed": Blueshirt masculine identity 1932-36', both in Caroline Magennis and Raymond Mullen (eds), Irish masculinities: reflections on literature and culture (Dublin, 2011), pp 13-34, 119-34.

${ }^{11}$ Olwen Purdue and Jonathan Jeffrey Wright, 'Introduction' in Georgina Laragy, Olwen Purdue and Jonathan Jeffrey Wright (eds), Urban spaces in nineteenth-century Ireland (Liverpool, 2018), pp 2, 6.

12 Erika Hanna and Richard Butler, 'Irish urban history: an agenda' in Urban History, xlvi, no. 1 (2019), pp 4, 7. For an overview of Irish urban history see, in same issue, David Dickson, 'What happened to modern Irish urban history?', pp 10-20.

13 'Edgar Milligen - gross indecency. Bill No. 16 (1917)' and 'Edgar Milligen - gross indecency. Bill no. 17 (1917)' (P.R.O.N.I., Belfast Crown Court records, BELF/1/1/2/52/ 19-20 [hereafter: 'Edgar Milligen - gross indecency']).

14 'Vincent Cassidy - buggery. Bill No. 53 (1917)' and 'Vincent Cassidy - buggery. Bill No. 54 (1917)' (P.R.O.N.I., BELF/1/1/2/54/25 [hereafter: 'Vincent Cassidy - buggery']). 
for this period and, even when it does, often contains only basic details (such as name, age and charge). ${ }^{15}$ The thick description of experiences, desires and understandings that characterise the Belfast depositions accordingly make them an unrivalled and uncommon source for reconstructing both the practices and meanings of 'queerness'. Nonetheless, such materials are not without methodological issues. The voices of the accused are usually obscured; arresting officers recorded protestations and excuses, and witnesses quoted conversations too, but most defendants exercised their right to say nothing until their assize trial (of which no descriptive records remain). Written down by the petty sessions clerk to be used as evidence for the prosecution, it seems likely that the statements of witnesses were at least partially made to conform to the criminalising language of the court. Their statements could be unreliable anyway; if caught having sex with another man, crafting a narrative that placed the blame on their partner, absolving them of guilt or suspicion of their masculine virtue, was a tempting option. As a result, piecing together how experiences actually happened, and what they might have meant to the participants, requires careful reading of these 'contradictory' sources - both of what was said and what was not - to get at the meanings they contain. ${ }^{16}$

The sexual landscape I reveal will be recognisable to historians of sexuality, if microcosmic compared to major metropolises that housed more visible subcultures. Each man used the booming city to find sex, with transnational formulations of class, respectability and masculinity shaping the sexual understandings of those involved and the response of the authorities. Urban cruising in public and publicprivate spaces, sexual relationships based not just on desire but opportunity, power and payment: these were common denominators of 'modern' urban homosexuality. But there were also idiosyncratic aspects to Ulster's queer culture. Belfast was merely one node that shaped queer knowledge and experiences, located within a peculiarly Irish network of places: urban and rural, in and beyond Ireland. Conversely, the religious divides that shaped Ulster also marked same-sex relationships, from public depiction to how participants fared in the legal system and their lives after trial. Using the prisms of masculinity and urbanity to unpack both the familiarities and peculiarities of 'queer Belfast', I thus aim to raise a new agenda for studying male sexuality in Ireland - one that notes political and literary approaches but is not constrained by their boundaries.

Historians have been well attuned to the importance of the modern urban environment in facilitating and shaping sexual interactions and identities. ${ }^{17}$ Urban street

15 Helen Smith, Masculinity, class and same-sex desire in industrial England, 1895-1957 (Basingstoke, 2015), pp 15-17. Inventive historians, of course, find other ways to write excellent queer history. As well as Smith, see Daryl Leeworthy, A little gay history of Wales (Cardiff, 2019). The material for Scotland for this period has more depth: see Jeffrey Meek, Queer voices in post-war Scotland: male homosexuality, religion and society (Basingstoke, 2015), pp 13-38.

16 Matt Houlbrook, Queer London: perils and possibilities in the sexual metropolis, 1918 1957 (Chicago, 2005), p. 5.

${ }^{17}$ For a useful overview, see the review essay by Phil Hubbard, 'Queering the city: homosociality and homosexuality in the modern metropolis' in Journal of Urban History, xxxiii, no. 2 (2007), pp 310-19. 
culture - the jostling of many bodies in one space, and the ability to stare, linger or strike up a conversation - created opportunities. New or expanding transport systems (such as subways and trams) were meeting points too, and also had the effect of creating spatial and emotional distance between centralised workplaces and the moral control of suburban home-life. Commercialised spaces of leisure and entertainment at the heart of the city enabled social mixing, collapsing or at least blurring class distinctions. For men that desired men, the city, though not without its dangers, could represent a land of homo-erotic possibilities. ${ }^{18}$ Belfast was not a metropolis on the scale of London or New York, but, by the turn of the twentieth century, it was still a booming industrial city and unrivalled regional capital. As economic opportunities proliferated, particularly in linen and shipbuilding, so too did the city's population. By 1911, around 386,000 people were living in the city and it was the biggest in Ireland (only Dublin, with 305,000, came close); factoring in Belfast's metropolitan area the total figure was closer to $515,000 .{ }^{19}$ Such growth, coupled with the expansion of a comprehensive tramway system, meant that private residences of the centre were increasingly replaced by commercial premises: department stores, offices, hotels and civic buildings. ${ }^{20}$ If Belfast remained residentially segregated by religion, the 'visually and linguistically indistinguishable' nature of the two communities meant that 'something approaching complete integration could be achieved' in this new city centre. ${ }^{21}$

Belfast was thus primed for a queer cruising culture. Between the de Cobain conviction in 1893 and the creation of Northern Ireland in 1921, however, the Belfast courts only tried thirty-one cases of 'gross indecency', the 'unnatural offence' that had been recriminalised in the United Kingdom of Great Britain and Ireland under the Criminal Amendment Act of $1885 .^{22}$ The First World War, a period when homosexual transgressions (and errant sexuality in general) 'aroused greater anxiety' and more alert policing, did see a higher rate of arrest: seven of the thirty-one cases occurred between 1914 and $1918 .{ }^{23}$ Regardless, these figures are hardly significant since overall they equate, roughly speaking, to a rate per year of one arrest for every 315,000 people - similar to Dublin, twice as high as the

${ }^{18}$ I have been particularly informed here by the approach of: George Chauncey, Gay New York: gender, urban culture, and the makings of the gay male world, 1890-1940 (New York, 1994), pp 179-206; Matt Cook, London and the culture of homosexuality, 1885-1914 (Cambridge, 2003), pp 22-41; and Houlbrook, Queer London, pp 43-67.

${ }_{19}$ Frederick W. Boal, 'Big processes and little people: the population of metropolitan Belfast 1901-2001' in Boal and Stephen A. Royle (eds), Enduring city: Belfast in the twentieth century (Belfast, 2006), p. 59.

${ }^{20}$ Austin Smyth, 'Return from Motown?' in Boal and Royle (eds), Enduring city, p. 103.

${ }^{21}$ A. C. Hepburn, A past apart: studies in the history of Catholic Belfast, 1850-1950 (Belfast, 1996), p. 122.

${ }^{22}$ The maximum sentence for buggery under the Offences Against the Person Act 1861, still in operation at this time, was life with a minimum of ten years. Some crimes were recorded as 'buggery' in this period, including Vincent Cassidy's, but no sentences beyond two years were given; it would seem that all homosexual crimes in this period were prosecuted under the 'gross indecency' clause of the 1885 act. Of these, the majority were 'consensual' between males over sixteen (today's age of consent). Some, however, related to: the clear sexual abuse of children; unwanted advances from one adult to another; and sexual assault of - usually younger - adults. Deconstructing the power relations for all these cases is beyond this article's scope, but is vital work for the future.

${ }^{23}$ George Robb, British culture and the First World War (Basingstoke, 2002), pp 81-2. 
urban north of England but three times lower than London. ${ }^{24}$ But absence of arrest is not evidence of queer absence. There was a strong desire to 'clean up the capital' in England, which led to higher levels of policing relative to other places. The Royal Irish Constabulary in Belfast - materially constrained, demoralised and uniquely facing a potentially revolutionary population - were not actively seeking out men who had sex with men. ${ }^{25}$ Statistics, then, are somewhat redundant when it comes to quantifying or even estimating the actual incidence of homosexual interactions. What we can do, though, is use well-documented cases to recreate the situations in which men met and how they lived a 'queer' life against the grain of Edwardian society.

The interactions that led to the arrests of both of the men in this case study happened right in the centre of Belfast, within four hundred metres of each other and a stone's throw from the crowning glory of the Edwardian City Hall. Hugh Sheehan, a twenty-two-year-old medical student at Queen's University Belfast, described how he was lounging about on Donegall Place on 1 September 1917 with a group of friends when Vincent Cassidy approached and asked 'generally' if 'any' of them would 'stop with him' in his hotel, to which Sheehan 'consented'. ${ }^{26}$ Queer men had practiced methods of publicly performing their openness to an approach without inadvertently alerting the less aware, exploiting the 'fluidity and multiplicity of the modern city'. ${ }^{27}$ Under cross-examination, it also became clear that Sheehan had a mutual friend who 'introduced' him to Cassidy; the student was already moving in circles that made him ready for an urban approach. ${ }^{28}$ Edgar Milligen, who came into the city to work at his father's offices in Donegall Square, focused his attention on the busy streets around the Great Northern Railway Station. Witness statements from two fifteen-year-old newsboys, Joseph Thompson and Eddie Wilson, described what was clearly an established cruising ritual. In April 1916, they were selling newspapers when they spotted Milligen - a man they already knew. Milligen first went into Robinson's Bar, then came out and 'walked up and down the street in front of the bar'. Albert McCutcheon, another boy who was with Thompson and Wilson, apparently approached Milligen after he had 'looked' at them, and struck up a conversation by saying 'that's a nice night Mr Milligen'. The newsboys then went and 'waited at the door' of the Kelvin Ice Cream Shop, presumably expecting the older man to follow them in - which he did. ${ }^{29}$

If interactions could begin on the streets, indoor spaces also provided an opportunity for men to meet. Edwardian Belfast had a pub or licensed shop for every 328

${ }^{24}$ Calculated from statistics for arrests between 1895 and 1915 for Northern England and London, and 1900-1915 for Dublin, in Earls, 'Queering Dublin', p. 115; Smith, Masculinity, class and same-sex desire in industrial England, p. 26; and Cook, London and the culture of homosexuality, pp 151-2. Even these statistics must be approached with extreme caution; like in Belfast, incidences may have been sexual abuse and, as Cook notes, the figures for London included bestiality.

${ }^{25}$ Mark Radford, The policing of Belfast 1870-1914 (London, 2015).

26 'Vincent Cassidy - buggery'.

${ }^{27}$ Mark W. Turner, Backward glances: cruising the queer streets of New York and London (London, 2003), p. 9.

28 'Vincent Cassidy - buggery'.

29 'Edgar Milligen - gross indecency'. 
inhabitants, though, as far as is possible to tell from surviving records, none seem to have housed a dominant queer subculture in this period. ${ }^{30}$ There are signs, however, that homosexual interactions could take place against the backdrop of ostensibly 'heterosexual space'. Sheehan described how he and Cassidy made frequent visits to music halls and supper saloons where they consumed meat, fish, oysters and wine. $^{31}$ More indicative, though, was the relationship between Milligen and another street lad called Patrick O'Donnell. Aged about fourteen or fifteen in 1914 when he first met Milligen in the Bodega Bar on Callender Street, O'Donnell made his living by singing at the theatre and horse-racing courses, selling newspapers and postcards around the pubs and milking cows in the market. Milligen regularly paid the boy to fetch taxis and, in 1915, bought him a new navyblue suit. In June 1916, about six months before O'Donnell's seventeenth birthday, Milligen took him to the Empire Theatre. Two men, or a man and an adolescent boy, could converse in taverns, supper saloons and theatres, and even pick each other up, without necessarily raising suspicion that they were lovers.

Finding a place to have sex could be trickier, though Milligen often risked it in remarkably public places. Once he had followed Thompson, McCutcheon and Wilson into the ice cream parlour and took up a booth, two of the newsboys took it in turns to masturbate the older man's 'tool' until 'white stuff came out'. After Milligen cleaned himself up with his handkerchief, he gave McCutcheon five shillings or half a crown, which the boy kept all to himself. Towards the end of the month, Thompson and Wilson told the court how they witnessed Milligen doing the same with two other young men; the first sexual interaction between Milligen and O'Donnell, after their night at the theatre, also took place in the parlour. ${ }^{32}$ There are other examples of men having sex in visible places in Edwardian Belfast, commonly toilets (including a popular 'cottage' in the Great Northern Railway Station), but also parks and alleyways/entries. ${ }^{33}$ For the young working class especially, without a place of their own and living with large families in overcrowded houses or many others in boarding rooms, indoor privacy was not an option; public places for sex had to suffice.

There were, however, some safer places in the city for those who had the money. Hotels, a public-private space 'outside police surveillance', offered seclusion if the owners were willing to 'ignore propriety' to maintain an income. ${ }^{34}$ After O'Donnell and Milligen left the ice cream parlour, they went to the Great Northern Railway Hotel (Milligen having missed the last train home to Lambeg). He apparently told 'the lady in charge' that O'Donnell was his 'son' - a lie he repeated at the hotel a few nights later. The next month, Milligen took O'Donnell to the Empire Hotel on York Street. They were not alone this time, but travelling with his servant, Millar, who was also the husband of his housekeeper. Milligen, wanting privacy, asked for two rooms, but only one with two beds was left and, despite his servant's presence, Milligen again had intercrural sex with his 'nephew'. O'Donnell told the court that Milligen 'gave the landlady a pound note' as well as half a bottle of

${ }^{30}$ Jonathan Bardon, 'Popular culture' in Boal and Royle (eds), Enduring city, p. 277.

31 'Vincent Cassidy - buggery'.

32 'Edgar Milligen - gross indecency'.

${ }^{33}$ See, for example: toilets - 'Joseph Rea and Thomas Magee - gross indecency (1913)' (P.R.O.N.I., BELF/1/1/2/41/33); parks - 'Patrick Hughes - gross indecency (1913)' (P.R.O.N.I., BELF/1/1/2/41/22); and entries - 'George Davidson - gross indecency' (1911) (P.R.O.N.I., BELF/1/1/2/35/31).

${ }^{34}$ Houlbrook, Queer London, pp 122-3. 
whiskey, perhaps suggesting that she had been bribed for her silence. Minnie Cunningham, the landlady in question, confirmed under cross-examination that she had 'treated this as an ordinary business transaction of persons looking for rooms' and that, because her hotel was 'near the Midland Railway ... people often [came] late at night looking for rooms'. 35

In the case of Cassidy, hotel employees even abetted queer culture. Cassidy was staying at the Imperial on Donegall Place, the same street where he had picked up Sheehan. One of the city centre's grander establishments, in 1915 the hotel was advertising itself as having 'moderate prices, combined with excellent cuisine and good attendance' and as 'most centrally situated for business or pleasure'. ${ }^{36}$ Cassidy found plenty of the latter; his parties in his bedroom and sitting room attracted as many as eleven men at once, both soldiers and civilians, and Sheehan claimed that up to five men 'occupied the bed' (eventually another mattress was also brought into the bedroom). No maids or landladies were called by the prosecution or defence to testify but, from the statements of other witnesses, nobody seemed to question Cassidy's behaviour. According to Francis Kavanagh, a corporal in the Dublin Fusiliers who revealed to the police what was happening in the hotel, Cassidy was on good enough terms with the staff to have 'sent a waiter to look' for him one evening. In the mornings, at about ten or eleven o'clock, 'the usual practice' was also for a maid to bring up food and the men to have 'breakfast in bed' together. ${ }^{37}$ During the First World War, soldiers-on-leave sharing rooms and even beds to save money might not at first glance have aroused suspicions. But there was an economy of queerness too; hotels and their employees likely understood for what their establishments were being used but, given the lack of active policing by the authorities, turned a blind-eye in the pursuit of profit.

Both Vincent Cassidy and Edgar Milligen had probably become familiar with how to pick up willing partners through their travels, experiences and connections in large cities with notable queer subcultures. Cassidy spent most of his childhood in Armagh, where his father was a saddler (his mother died in 1904 when he was just thirteen). ${ }^{38}$ After schooling in Dublin at the Christian Brothers' College, he attended the grammar Strand School in London for several months in 1909, staying in Highbury with a relative who was a bank clerk. ${ }^{39}$ In 1911, he was still in London and working as a bank clerk himself, but now living in a boarding house run by an old widow and her daughters. Aged nineteen, he was the youngest of seven other male boarders, all clerks and in their twenties, and from English, Welsh, Irish and German backgrounds. ${ }^{40}$ In March 1915, he had left London and was setting sail from Liverpool on the Lusitania, bound for New York and listing himself as a 'secretary'. ${ }^{41}$ While in New York, he was apparently 'in the employment of a

35 'Milligen - gross indecency'.

${ }^{36}$ Northern Whig, 3 July 1915.

37 'Vincent Cassidy - buggery'.

381901 census of Ireland, House 6 Ogle Street (South Ward, Armagh), accessed online: N.A.I. (http://www.census.nationalarchives.ie) (4 Mar. 2020) [hereafter N.A.I. census]; Irish News and Belfast Morning News, 31 Mar. 1904.

39 Vincent Cassidy, no. 558 (London Metropolitan Archives, school admission and discharge registers, LCC/EO/DIV08/STR/AD/002).

401911 census returns of England and Wales, 140 Tufnell Park Road (T.N.A., series RG14, 1911).

${ }^{41}$ Lusitania leaving Liverpool, 20 Mar. 1915 (T.N.A., Board of Trade: Commercial and Statistical Department and successors: outwards passenger lists, BT27). 
German'. ${ }^{42}$ We might speculate that Cassidy had met this 'German' through Max Ernst and Hans Wiechert, his housemates in London, and wonder further if there was a financial reward beyond simple 'employment', given the life that Cassidy maintained in the Imperial. On his journey home to Ulster in late August 1917, Cassidy again passed through Liverpool, the 'hub of the Irish diaspora', and appears to have made a connection there with Jack Fearon, a 'young man' who held a commission in the King's Liverpool Regiment. ${ }^{43}$ Francis Kavanagh had also met Fearon, in nearby Formby, where they had been training in the same camp. When Kavanagh had later travelled from Dublin to Belfast to see a 'comrade', he had met Fearon in Castle Place, just around the corner from the Imperial where he too was staying. 'In consequence' of what Fearon 'told' him, Kavanagh left his own bedroom in the hotel to go to Cassidy's. ${ }^{44}$ The context of the war also encouraged this homosocial culture, the 'all-male environment of the military' helping to 'foster intimate friendships between men' and furthering 'the expression of male emotion'. 45

Edgar John Milligen was of a higher class than Cassidy and in no need of a benefactor (beyond his own wealthy father). But he did capitalise on the good fortune of his background to move around. Born in 1886, he had been educated at Harrow. ${ }^{46}$ Presumably he would have been familiar with London, given the proximity of that elite school to the metropolis and the backgrounds of the privileged pupils who studied there. As a merchant in his father's business, and with easy access to money, it seems likely that Milligen would have had travelled too. He was arrested in Liverpool, and it is likely he had links to other parts of England and Scotland. ${ }^{47}$ Wartime further facilitated male movement, but Irish society was already marked by the 'networks of exchange' that transmitted both people and information across the global north. ${ }^{48}$ Though Belfast did not face the same degree of 'endemic'

42 Irish Independent, 29 Nov. 1917.

${ }^{43}$ St Louis arriving in Liverpool, 26 Aug. 1917 (T.N.A., Board of Trade: Commercial and Statistical Department and successors: inwards passenger lists, class, BT26; piece: 637). See John Belchem, Irish, Catholic and Scouse: the history of the Liverpool-Irish, 1800-1939 (Liverpool, 2007).

44 'Vincent Cassidy - buggery'.

${ }^{45}$ Robb, British culture and the First World War, p. 82. Oral histories recorded in the 1970s with queer former servicemen testify to this culture of intimacy and opportunity: see Kevin Porter and Jeffrey Weeks (eds), Between the acts: lives of homosexual men 1885-1967 (London, 1991), pp 5-8, 15-16, 25-6.

461901 census returns of England and Wales, Harrow (T.N.A., class: RG13; piece: 1207; folio: 54 ; p. 22).

47 Though Liverpool's Irish population was popularly conceived as being made up largely of the working class, John Belchem reminds us that there was an 'Irish presence above the unskilled sector' and 'professional networks ... which criss-crossed the Irish Sea': Belchem, Irish, Catholic and Scouse, p. 38. Donald MacRaild, meanwhile, has stressed the importance of 'cultural institutions' that served the Irish Protestant diaspora in northern England, such as the Orange Order (of which, following his Scottish father, Milligen was possibly a member): Donald M. MacRaild, 'Networks, communication and the Irish Protestant diaspora in northern England, c.1860-1914' in Enda Delaney and Donald M. MacRaild (eds), Irish migration, networks and ethnic identities since 1750 (London, 2007), pp 163-89.

${ }^{48}$ Enda Delaney and Donald M. MacRaild, 'Introduction' in idem (eds), Irish migration, networks and ethnic identities, p. xiv. 
permanent emigration as more rural parts of Ireland, much of its population was prepared to move for work (if of the labouring classes) or education (if middle or upper class). ${ }^{49}$

Cities were by no means the only nodes in this network; Belfast, after all, was primarily a place of 'in-migration' from the surrounding Ulster countryside. ${ }^{50}$ Bob Webb, a twenty-five-year-old butcher and Hugh Sheehan's 'best pal', was also at Cassidy's party. ${ }^{51}$ He was from Armagh, the son of a flax buyer; born in the same year as Cassidy and living just one street away, the two young men almost certainly knew each other. ${ }^{52}$ By 1911 , like so many others, Webb had moved to Belfast to find work. Living with his four older sisters, two older brothers and a cousin on Springfield Road, he probably worked at a nearby butchers on the Falls Road run by another brother. At any rate, Webb was now in the same neighbourhood as Sheehan. ${ }^{53}$ Cassidy had seemingly brought his friendships from Armagh to Belfast, but he continued to maintain connections to small town and rural Ulster. He and Sheehan took a 'considerable number' of taxi journeys during their courtship for example, to Bangor, a well-to-do mid-sized resort and Belfast commuter town. More surprisingly, Sheehan said that when Cassidy 'took' him to Armagh they went 'to [Cassidy's] father's house'; they also went to meet his 'married sister' in Ardboe, a village in County Tyrone (near Killywoolaghan, where Cassidy was later arrested). ${ }^{54}$ Milligen, too, had no qualms about taking the young O'Donnell in a taxi to his country mansion, Glenmore House, in Lambeg. We should, then, 'remain conscious of the regular reminders' of 'the surrounding countryside' and the 'close connections through family ties' that linked urbanites — including queer men - back to their roots in contemporary Ireland. ${ }^{55}$

Cassidy and Milligen met their young men or adolescent boys on the streets, and socialised in pubs, theatres and hotels. In this way, their experiences suggest the familiar importance of the urban, in Ireland as elsewhere, in the facilitating of sexual encounters. Friendships in other cities beyond were also influencing how men found sex in Belfast, creating networks of knowledge that transgressed national and cultural boundaries. However, older and less urban relationships did not necessarily disappear; if modern homosexuality was commonly marked by a movement to the city, and the suburban separation between home and work, in Ireland 'an intricate web of kinship' still bound 'together town and country'.56

49 Liam Kennedy, Lucia Pozzi and Matteo Manfredini, 'Edwardian Belfast: marriage, fertility and religion in 1911' in Olwen Purdue (ed.), Belfast: the emerging city 1850-1914 (Dublin, 2013), p. 188.

${ }^{50}$ Ibid., p. 187.

51 'Vincent Cassidy - buggery'.

521901 census of Ireland, House 10 in Irish Street Upper (South Ward, Armagh) (N.A.I. census).

531911 census of Ireland, House 250 in Springfield Road (Falls, Antrim) (N.A.I. census); 1911 census of Ireland, House 281 in Springfield Road (Woodvale, Antrim) (N.A.I. census).

54 'Vincent Cassidy - buggery'.

${ }^{55}$ Brian Lambkin, Patrick Fitzgerald and Johanne Devlin Trew, 'Migration in Belfast history: trajectories, letters, voices' in Purdue (ed.), Belfast, p. 247.

${ }_{56}$ Leslie Clarkson, 'The city and the country' in J.C. Beckett (ed), Belfast: the making of the city (Belfast, 2008), p. 156. 
In the 'new queer history', scholars have moved away from medical and legal theories of the creation of 'the homosexual' to stress the diversity of experiences and identities of men who had sex with men. In doing so, they have disrupted the notion of a stable sexuality binary in the past and highlighted how 'queerness' did not necessarily denote the opposite of 'normality'. 57 As yet, this new approach has not been applied to sexuality in the urban north of Ireland. Both George Chauncey and Matt Houlbrook, however, have drawn attention to how Irish migrants in New York and London in this period were not just open to casual samesex interactions in return for payment, but lived outside many heteronormative expectations more broadly. While they were single, they rejected the 'conventions of family life and domesticity' and the bourgeois 'manners associated with the domesticating and moralizing influence of women'. To do so did not necessarily entail the damaging of their masculinity; rather, 'manliness' in the 'tough bachelor culture' of crowded boarding houses was proven through the performance of gendered dominance in all relationships - sexual and non-sexual - and by conforming to ideals of 'camaraderie' and 'fraternity'. ${ }^{58}$ Men could certainly risk 'forfeiting' their 'masculine status by being sexually passive', but, crucially, they could also establish it by 'playing the dominant role'. In this homosocial world, women were mostly absent and money could instead provide a justification for engaging in same-sex behaviour. When coupled with the Catholic Church's 'silence' about the sins of same-sex desire, at least in comparison to premarital intercourse, Irishmen 'accepted' sex with other men 'as part of everyday male life'. 59

In Belfast, adolescents and adults, both Catholic and Protestant, lived under similar socio-economic conditions and, indeed, had often experienced (or even exported) that homosocial culture abroad. In the case of Milligen's newsboys, who 'were only just above the position of beggars' in wealth and status, unashamed openness to having sex with men intermeshed with financial precarity. ${ }^{60}$ Albert McCutcheon, for example, painted by Eddie Wilson and Joseph Thompson in absentia as the ringleader, was from a poor background. His father, a sawyer, was a County Tyrone man, whereas his mother was a Belfast-born illiterate domestic servant. In 1911, he was the third youngest of seven living children, nine of his siblings having died, and the family of eight was living in a four-roomed house on Matilda Street in the inner-city neighbourhood of St George's. ${ }^{61}$ Though McCutcheon was not destitute, sex could supplement meagre wages. O'Donnell, an orphan of 'no fixed abode', had even more need to get off the streets. Such was the state of his clothes when Milligen first took him to the Empire Hotel, the landlady tried to refuse his stay; Milligen consequently gave him $£ 2$ for another

${ }^{57}$ Smith, Masculinity, class and same-sex desire in industrial England, p. 6. For an overview of this shift, see Chris Waters, 'Distance and desire in the new British queer history' in GLQ: A Journal of Lesbian and Gay Studies, xiv, no. 1 (2008), pp 139-55.

${ }_{58}$ Quotes from Chauncey, Gay New York, pp 80-81. See also Houlbrook, Queer London, pp $189-90$.

${ }^{59}$ Houlbrook, Queer London, p. 189.

${ }^{60}$ Stephanie Rains, 'City streets and the city edition: newsboys and newspapers in early twentieth-century Ireland' in Irish Studies Review, xxiv, no. 2 (2016), p. 148.

${ }^{61} 1911$ census of Ireland, House 160 in Matilda Street (St George's, Antrim) (N.A.I. census). 
suit, pair of boots, shirt and cap, which the boy spent in Spackman's tailors and pawn offices across the city. Milligen also had O'Donnell over to his big house 'five or six times' (though the frequency remembered by the boy was challenged by Milligen's housekeeper), where there was 'a good deal of drink going on', and he slept over too (the housekeeper again disputed that they shared a bed). Their relationship ended when O'Donnell stole about $£ 12$ or $£ 13$ from Milligen's waistcoat - money which he spent in Bangor, Belfast and Liverpool - after the older man had not given him $£ 50$ he was 'promised'. For O'Donnell, Milligen had been, if only for a brief time, an 'urban passport': a richer man who opened doors in the city that would usually be shut. ${ }^{62}$

Understanding or qualifying the desire of these adolescent boys is fraught with not just historical but ethical difficulties. ${ }^{63}$ We could assume that their experiences were distressing. Though there was no legal age of consent for sex between males, the intergenerational power differentials of fifteen- and sixteen-year-old newsboys and a twenty-nine-year-old industrialist are troubling. In their own words, however, we can recognise a degree of agency. O'Donnell refused to let Milligen 'get' at his 'back' after the man had 'got' him 'on his front'. But he also described how Milligen 'did not use any force' on him, and how he allowed Milligen, many times, to thrust between his thighs until 'he wet the bed below'. He admitted that he went with the older man repeatedly 'knowing that the same thing', namely sex, 'had happened' to him 'before' and he even maintained that Milligen 'was good' to him. The language in his statement suggested sexual naivety yet also intent, if not desire; he described how he frequently 'picked him [Milligen] up' in the Bodega Bar. ${ }^{64}$ Thompson and McCutcheon, according to the former, were also participants, and not forced or threatened. Eddie Wilson in contrast, of a similar class to McCutcheon, was clear that he 'did nothing' to Milligen and that, despite being poor, he chose not to have sex with an older man for money. ${ }^{65}$ Rather than expressing disgust or fear, however, Thompson and Wilson admitted that they 'laughed' or were 'giggling' when they spied on Milligen having sex with other young men. They were 'afraid of being caught', but seemingly by Milligen rather than the authorities. ${ }^{66}$ For poor working-class boys in Belfast, unguarded honesty may indicate their lack of knowledge about the accepted social and moral

62 'Edgar Milligen - gross indecency'. 'Urban passport' is a term used by Leif Jerram, Streetlife: the untold history of Europe's twentieth century (Oxford, 2011), p. 268.

${ }^{63}$ Rachel Hope Cleves has recently stressed the importance of not avoiding the 'sticky methodological challenges' of intergenerational sex, given its past prevalence, relationship to the construction of power and demonstration of a 'central tenet' of the history of sexuality namely, that 'sexual practices, desires, and identities, are historically constructed' and have thus 'changed over time': Rachel Hope Cleves, 'The problem of modern pederasty in queer history: a case of study of Norman Douglas' in Historical Reflections/Réflexions Historiques, xlvi, no. 1 (2020), quotes at pp 49, 58.

${ }^{64}$ See Earls, 'Solicitor Brown and his boy', for a similar dynamic from mid-century Dublin.

65 'Edgar Milligen - gross indecency'. Wilson was from the same neighbourhood and social class as McCutcheon; his parents were born in County Armagh, along with several of his siblings, and their family of eight lived in a six-roomed house on Charles Street (South) supported by his father's labouring and two adult children in the linen industry: see 1911 census of Ireland, House 109 in Charles Street, South (St George's, Antrim) (N.A.I. census).

66 'Edgar Milligen - gross indecency'. 
boundaries of sexual behaviour. ${ }^{67}$ Instead, in navigating the world of working poverty, satiating an older man was a means to a financial end: a normal if not necessarily pleasurable 'distinct moral economy' ${ }^{68}$

Hugh Sheehan's relationship with Cassidy also had an economic aspect. In the two-and-a-half months he stayed in the Imperial, Cassidy apparently 'paid all expenses including travelling' and 'treated' Sheehan frequently. ${ }^{69}$ Nevertheless, by no means was Sheehan in desperate need of financial support. His father, Timothy Sheehan, ran a spirit-grocer's on Cupar Street in the west of the city and was well-off enough to employ a domestic servant. ${ }^{70}$ Sheehan himself was at university, which, given the lower proportion of Catholics at Queen's, put him in a minority within a minority. ${ }^{71}$ He told the court: he 'did not know how to make a cocktail until [Cassidy] taught' him; 'never knew [Cassidy] to be guilty of any indecency' apart from that he had 'described' with himself; 'never would have mentioned' the sex if the police had not come to him; and even maintained that Cassidy was 'a decent man'. Cassidy was designated by the authorities as the ringleader despite the two men being a similar age but, from reading Sheehan's statement, this seems as much a friendship based on fun, homosociability and brotherly guidance as it was a simple cash nexus.

Sheehan was also open, and even enthusiastic, about their sexual relationship. Rather than describing Cassidy as a corrupting influence, he portrayed himself as fully aware and in control of what he wanted, and did not try to conceal his behaviour. He said his family 'knew' he 'was living in the Imperial Hotel and allowed it', he did not use the distance of the family house as an 'excuse', and he acknowledged that he 'was quite free to go home any time'. He also described how their sexual relationship was one of reciprocity, beginning with mutual masturbation and leading to anal penetration on at least ten occasions, with each man taking the 'active' role. Sheehan even told the constable that he did not make the statement 'to save' his 'own skin' - an unnecessary admission more suggestive of defiance than guilt. Indeed, under cross-examination by Cassidy's solicitor, Sheehan boasted of the extent of his worldly experience. Even before he 'knew' Cassidy, he said, he had 'read a little about medicine', 'knocked a little about town' and partook in 'midnight suppers'. He knew, then, 'what a young blood about town' was and believed he fell 'under that category'. At one point Sheehan did accept his 'abominable conduct', but seemed to be mimicking the language of the court or perhaps unknowingly had that sentiment recorded by the clerk; his statement, for the most part, read in the reverse. ${ }^{72}$ For this young man, homosexual interactions were not unnatural nor dishonourable: 'casual sex', as Matt Houlbrook puts it, had 'shaded into an ongoing and intimate relationship'. ${ }^{73}$

${ }^{67}$ Smith, Masculinity, class and same-sex desire in industrial England, p. 35.

68 Steven Maynard, "'Horrible temptations": sex, men, and working-class male youth in urban Ontario, 1890-1935' in The Canadian Historical Review, lxxviii, no. 2 (1997), p. 196.

69 'Vincent Cassidy - buggery'.

${ }^{70}$ Irish News and Belfast Morning News, 21 Sept. 1901, 30 Jan. 1907, 10 Nov. 1908.

${ }^{71}$ In 1911 , only $17 \%$ of the students were Catholic, despite making up around a quarter of the population: Hepburn, A past apart, p. 129.

72 'Vincent Cassidy - buggery'.

${ }^{73}$ Matt Houlbrook, 'Soldier heroes and rent boys: homosex, masculinities, and Britishness in the Brigade of Guards, circa 1900-1960' in Journal of British Studies, xlii, no. 3 (2003), p. 360 . 
We cannot know for sure, but we might deduce that the frankness of witnesses was encouraged by the police and the clerk to ensure the conviction of the middle- or upper-class men designated as sexually corruptive. ${ }^{74}$ Their honesty nonetheless attests to the existence of a homosocial subculture in Belfast in which males could have sex with each other, whether for financial gain or simple desire, and without either ascribing a 'homosexual' identity to themselves or damaging their sense of masculinity. For Sheehan, sleeping with men even seemed to be more respectable than with women of lower morals. At one point he stressed how he had 'been with music hall girls' but not 'pantomime girls', drawing 'a line between' the two. ${ }^{75}$ Milligen, as a man from a higher social class armed with the knowledge that came with a transnational network, took advantage of workingclass 'innocence and ignorance' to find sexual partners. ${ }^{76}$ Both he and Cassidy could bring their partners into their lives too, whether that be with friends and employees, as with Millar in the case of Milligen, or family, like Cassidy with his father and sister. Away from the courts, male homosexual relationships happened for a variety of reasons and often without a strong notion of wrongdoing; in the courts, when the threat of punishment was on another man and not themselves, they could explain their behaviour honestly and without much remorse. In a way, as Harry Cocks argues, the 'namelessness of the crime' could even 'provide certain paradoxical opportunities for homoerotic expression'. ${ }^{77}$ When relative silence in the press was combined with the lack of an active approach from the police, a 'freedom and open space to behave outside proscriptive norms' could arise, shattering the deviant narrative propagated by the law. ${ }^{78}$

In both cases, investigations arose following reports by men who were not willing to breach those norms. Many months after Eddie Wilson had witnessed his friends masturbate Milligen, he was encouraged by a 'Mr Nesbitt', perhaps a charity worker, to make a 'complaint' to the police. ${ }^{79}$ Cassidy's downfall was due more to misfortune. When Francis Kavanagh was arrested for desertion in mid-November, his regiment having returned to Aldershot five weeks previously, it became clear that he had skipped the bill from the hotel where he had been staying under a false name, though 'to avoid' his family, he claimed, rather than the army. Hard up for cash, he had also 'borrowed' a coat from a waiter and pawned it for a

${ }^{74}$ Portraying upper-class men as 'perverters' of youth was a common trope, especially during the various late nineteenth-century homosexual scandals between elites and working-class adolescents: See Sean Brady, Masculinity and male homosexuality in Britain, 1861-1913 (Basingstoke, 2005), pp 95-6.

${ }^{75}$ Sheehan's distinction reflected the wider stereotypes of class and respectability applied to the 'modern woman' of the early twentieth century. 'Pantomime girls', for example, were sometimes caricatured in the press as potentially lascivious and degenerate - like, for example, in the cautionary tale of 'A girl's downfall' in The Times, 12 June 1914. Concerns about the behaviour of young working-class women were evident in Belfast at this time: see Leanne McCormick, 'The dangers and temptations of the street: managing female behaviour in Belfast during the First World War' in Women's History Review, xxvii, no. 3 (2018), pp 414-31.

${ }^{76}$ Smith, Masculinity, class and same-sex desire in industrial England, p. 51.

${ }^{77}$ Harry Cocks, Nameless offences: homosexual desire in the 19th century (London, 2003), p. 7. We should not however, as Cocks demonstrates, equate the attempt to limit discourse about sexuality with a lack of public knowledge.

${ }_{78}$ Smith, Masculinity, class and same-sex desire, p. 160.

79 'Edgar Milligen - gross indecency'. 
few shillings. Kavanagh told the police about Cassidy and Sheehan at the hotel, perhaps as a way - seemingly successful - to distract from his own crimes. ${ }^{80}$ The vast majority of cases tried in Belfast before 1914 had concerned men 'caught in the act' in public spaces; relationships that happened mostly behind closed doors were harder to police and seemingly left alone. But against a backdrop of moral panics and the belief that sexual deviance was 'a crime against a civilian society at war', in these two cases Belfast detectives breached the public-private boundary and went to uncharacteristically extensive lengths to collect the evidence needed to secure a conviction. ${ }^{81}$

Recent studies have stressed the importance of discourses of masculine respectability in structuring legal responses to homosexual 'crimes', especially given the difficulty of prosecuting an act that often, as was partially the case here, took place in private. If a defendant could portray themselves as an upstanding member of the community, who satisfied hegemonic masculine ideals in the spheres of work, home and - especially for middle-class men - public life, they could portray themselves as simply incapable of committing a homosexual act. In contrast, if witnesses, including the working class, were demonstrated to be unrespectable, their statements could be disregarded. ${ }^{82}$ To a degree, the two cases here followed these classed models of masculine virtue. But they were also shaped by an intersection with religious and political identities. Proving respectability was more likely, it seems, if a man's public life was intertwined with that of the Ulster unionist elite.

Edgar Milligen's solicitor focused on discrediting the respectability of the newsboys by leading them to describe their own brushes with the law. Thompson admitted being 'charged with breaking and entering once', and added that 'Wilson [had] been in trouble for stealing a lady's handbag'. McCutcheon, the boys revealed, had been 'put in a home' in Glasgow 'for stealing boots'. ${ }^{83}$ Anxieties in Belfast about newsboys, who were seen by social reformers to occupy a 'distinct subculture' among street-trading children, were already high. ${ }^{84}$ Complaints about 'juvenile

80 'Vincent Cassidy - buggery'.

${ }^{81}$ Samuel Hynes, A war imagined: the First World War and English culture (London, 1990), p. 226. In most Belfast trials before the First World War, witness statements were limited to the arresting officer and sometimes a member of public who had spotted a couple having sex - a marked contrast to the parade of maids, landladies, ice-cream shop proprietors, taxi-drivers and housekeepers who gave statements in the cases of Cassidy and Milligen.

${ }^{82}$ Cocks, Nameless offences, showed how trials for sodomy interacted with understandings of masculinity and character, emphasising the importance for middle-class men accused. Brady extended this analysis to working-class witnesses and defendants too, arguing that 'the possession of a respectable "character" ... was essential ... irrespective of class': Brady, Masculinity and male homosexuality in Britain, p. 21. Particularly influential here has been the work of John Tosh: see his 'Hegemonic masculinity and the history of gender' in Stefan Dudink, Karen Hagemann and Josh Tosh (eds), Masculinities in politics and war: gendering modern history (Manchester, 2004), pp 41-58.

83 'Edgar Milligen - gross indecency'.

${ }^{84}$ Gillian McIntosh, 'Children, street trading and the representation of public space in Edwardian Ireland' in Maria Luddy and James Smith (eds), Children, childhood and Irish society: 1500 to the present (Dublin, 2014), p. 60. 
rowdyism' and the 'hideous yelling, objectionable horse-play, disgusting language, and insulting remarks to passersby' were common, as were cases of petty theft. ${ }^{85}$ The witnesses' patronage of the ice cream shop may have also been suggestive for the jury. The 'mischievous influence' of these establishments had long been blamed for 'foster[ing] immorality' among 'young lads and girls' ${ }^{86}$ Open late, often licensed and with gambling machines, they were a key target of Ulster's temperance movement. ${ }^{87}$ The First World War heightened these fears. Around the time that Milligen was arrested, a Belfast judge singled out ice cream shops and the cinema as causes of 'our young people ... going to the devil while our soldiers are fighting at the front' ${ }^{88}$ Not long after, the philanthropist Lady Dufferin met with the Belfast City Council to express similar concerns. '[C]onditions of war', she argued, had 'led to great excitement' that incited 'acts of folly and misconduct and immorality' among 'the youth'. Her description of 'vicious proceedings' and 'incitement to evil' in the 'demoralising atmosphere' of ice cream shops were coded references to prostitution and sex - and, given past notorious scandals, possibly the sexual dangers of the city for male working-class youths too. ${ }^{89}$

How Milligen justified to the court his socialising with such immoral adolescents and in such an undesirable location we cannot now know, but we might make an educated guess. Though much of the Irish press coverage of newsboys drew attention to their criminality, 'sentimental tales' about 'heroic newsboys' that were 'in need of rescue' from a difficult and dangerous life on the streets were also common. ${ }^{90}$ In October 1917, the same judge that had noted the corrosive influence of ice cream shops also argued that 'something ought to be done' for these 'poorly clad and half fed' newsboys. ${ }^{91}$ Milligen was ostensibly a philanthropist, following in the footsteps of his father (who was heavily involved in the increasingly influential Orange Order). In the war years, Edgar was a patron of the Belgian Refugee Relief Fund, holding fundraisers at his Lambeg house. He was also involved with the Black Diamond Club (a junior league football team) and manager of the Lambeg Village School (staging annual prize ceremonies for the pupils). ${ }^{92}$ As the Northern Whig described in a report unrelated to his arrest, he had 'always taken an active interest in the educational work of the district'. ${ }^{93}$ Milligen could have painted himself as a respectable charitable Christian who was being extorted

${ }^{85}$ Northern Whig, 21 Aug. 1916.

${ }^{86}$ Belfast News Letter, 22 May 1906. For context, see Francis McKee, 'Ice cream and immorality' in Harlan Walker (ed.), Proceedings of the Oxford symposium on food and cookery 1991 (London, 1991).

87 Orfhlaith Campbell, 'A platform upon which all could unite?: Temperance in Ulster and the Irish Temperance League, 1858-1914' (Ph.D. thesis, Open University, 2017), p. 2.

${ }^{88}$ Portadown News, 16 Sept. 1916; Northern Whig, 14 Sept. 1916.

89 Belfast News Letter, 2 Nov. 1917. Both the Cleveland Street Scandal (1890) and downfall of Oscar Wilde (1895) played into this narrative of young male prostitution: see Jeffrey Weeks, 'Inverts, perverts, and Mary-Annes: male prostitution and the regulation of homosexuality in England in the nineteenth and early twentieth centuries' in Journal of Homosexuality, vi, no. 1-2 (1980), pp 113-34.

${ }^{90}$ Rains, 'City streets and the city edition', p. 151.

91 Northern Whig, 29 Oct. 1917.

92 Milligen's father was heavily involved in local unionist culture, annually entertaining the 'Orangemen of the district' each 12 July: see Northern Whig, 19 Sept. 1947. For Milligen's charitable work, see Northern Whig, 8 Mar. 1915 and Belfast News Letter, 26 Jan. 1915.

93 Northern Whig, 13 May 1916, 3 May 1915. 
by the criminal youths he was trying to help. His reputation in this sense would have been augmented by the circles in which he moved. Hugh McAlinden, a married Armagh-born bookmaker then living in a salubrious part of Andersonstown, provided $£ 200$ for part of his bail. He was publicly known as the chairman of Belfast Celtic, owned racehorses and greyhounds too, and perhaps first met Milligen when the former judged whippet meets in Lambeg. ${ }^{94}$ When McAlinden died in 1938, the Belfast Telegraph described his 'big sympathetic understanding, which led him to be generous almost to a fault'; Milligen presumably would have agreed. ${ }^{95}$ The defendant's other surety came from Down-born Robert Quiery, another bookmaker who lived on Kansas Avenue. Quiery was the same age as McAlinden, also married with children and a man of some means. ${ }^{96}$ He lived just a few streets away from McAlinden, and was 'one of the best-known and most popular figures in Irish racing circles'. ${ }^{97}$

Even more impressive, however, were Milligen's legal connections. Just before the trial, Milligen's solicitor John Graham wrote to Dublin Castle and the Lord Lord Lieutenant of Ireland, Lord Wimborne, asking for permission for James Chambers to be 'Counsel against the Crown' in the case. Chambers, an Ulster Unionist M.P. for South Belfast, had just been appointed solicitor general for Ireland, one of the most senior legal governmental roles in the country. In the assize session when Milligen's case was heard, the Lord Chief Justice Ross addressed the incoming solicitor-general and said 'In common with hosts of friends I am delighted to see the announcement of your appointment', a comment that received 'applause in court'. 98

When Milligen had been apprehended by the police, he had apparently hesitated before saying: 'I am not going to say that I am guilty, although I cannot say I am entirely innocent. I know something about it', expressing how he was 'surprised that the boy's father did not come and see me instead of reporting it to the police'. 99 Milligen's admission suggests he 'had a similar understanding to the authorities of what having sex with other men meant in regard to the law' but that he expected to be able to act with relative, if not open, impunity. ${ }^{100}$ He was right: the court acquitted him without charge, in spite of the consistent and damning evidence. If he was not aristocracy nor even landed gentry per se, his wealth and Harrow education would have given him access to 'valuable and influential connections' and tied him into 'Britain's elite social and political network'. ${ }^{101}$ At home, meanwhile, he was a part of one of the several hundred families that formed a 'tight-knit' and influential community across business, politics and associational culture. ${ }^{102}$ Milligen, it seems likely, mobilised the social and political capital that came with being a wealthy Protestant unionist in the early twentieth century.

${ }^{94}$ Irish News and Belfast Morning News, 24 June 1911.

95 Belfast Telegraph, 29 Jan. 1938.

96 Nottingham Journal, 20 Sept. 1920.

97 Dublin Evening Telegraph, 22 May 1920.

98 Belfast News Letter, 21 Mar. 1917.

99 'Edgar Milligen - gross indecency'. O’Donnell was an orphan, so Milligen was likely referring to another boy - probably one of many.

${ }^{100}$ Smith, Masculinity, class and same-sex desire in industrial England, p. 44.

${ }^{101}$ Olwen Purdue, The big house in the north of Ireland: land, power and social elites, 1878-1960 (Dublin, 2009), pp 159-60.

102 W.A. Maguire, Belfast (Keele, 1993), pp 110-11. 
Vincent Cassidy, on the other hand, was a politically unconnected Catholic from Armagh at a time when 'the relative position of Catholics [had] probably worsened' due to the growth of militant nationalism and the consequent 'Protestant backlash'. ${ }^{103}$ In terms of respectability, the witnesses for the prosecution, though both Catholic too, were of a much higher social status than criminal newsboys. Sheehan, while honest about having sex with men, had a respectable, civically active father and his own family solicitor. ${ }^{104}$ He could have been portrayed as a decent if naïve young man tempted by the corrupting Cassidy. Kavanagh was, by his own admission, a thief and deserter, but also a corporal in the army and the son of a successful Cork solicitor, and his claim that he 'stopped' Cassidy's sexual advances was also corroborated by Sheehan. With percolating concerns about sexually vulnerable servicemen being corrupted by homosexual predators, Cassidy would have been disproportionately blamed by the authorities. ${ }^{105}$ He was itinerant, not working or active in public life, and known to associate with a German, an enemy equated with homosexual perversions by conservative wartime literature. ${ }^{106}$ When Cassidy was arrested he denied the charge, claimed to have 'never touched' Kavanagh, and tried to discredit the soldier by asking the constable if he knew the young man was a 'deserter from the army'. ${ }^{107}$ Unfortunately for Cassidy, this did not work and he was sentenced to twelve months' imprisonment with hard labour. ${ }^{108}$ Men from Protestant denominations outnumbered Catholics on the jury, reflecting the demographics of society more broadly: for Milligen, by at least four-to-one; and for Cassidy, by at least three-to-one and possibly higher. ${ }^{109}$

Just as telling as the verdicts was the approach of the local press. Neither Milligen's arrest nor trial was mentioned, in contrast to almost every other defendant tried in Belfast for the same crime in the previous three decades. The British establishment had a tendency of 'restrict[ing] investigations' and 'public discussion' of 'governing men' where possible when they were caught in homosexual scandals, but the remarkable crossover between the Ulster political elite and unionist newspaper editors may have helped too - especially during the strained conditions of the Home Rule Crisis and the War. ${ }^{110}$ Cassidy, in contrast, was named by

103 Hepburn, A past apart, p. 127.

104 Timothy Sheehan played an active role in the local community through nationalist and charitable causes: see Irish News and Belfast Morning News, 21 Sept. 1901, 30 Jan. 1907. For context, see Hepburn, A past apart, pp 127-35.

${ }^{105}$ Houlbrook, 'Soldier heroes and rent boys', pp 374-5.

106 Such as in John Buchan's Greenmantle (1916) where, as George Robb puts it, 'the villain is a sadistic German officer who is also homosexual': Robb, British culture and the First World War, p. 84.

107 'Vincent Cassidy - buggery'.

108 Cassidy could have been imprisoned for two years under the 1885 act; the court's leniency was likely because this was his first offence.

${ }^{109}$ We have the jurors' names, but no addresses; locating definite information about religious background, then, is difficult. In the case of Cassidy for example, census data from Down and Antrim, based on the admittedly unscientific assessment of the commonness of family name, suggests that eight of the jurors were almost certainly Protestant, one was likely Catholic (Boyle), whereas two (McAvoy and Connor) could have been either.

${ }^{110}$ Murgu, 'Innocence is as innocence does', p. 318. For newspapers, see Dennis Kennedy, The widening gulf: Northern attitudes to the independent Irish state, 1919-49 (Belfast, 1988), pp 11-24. 
the Irish Independent, Northern Whig and Belfast News Letter. Astute readers would have been able to discern his crime, especially through the News Letter, which reported how he "was charged with having committed an offence in a Belfast hotel' with the 'principal witnesses' being 'two youths named Hugh P. Sheehan and Corporal Francis Cavanagh'. ${ }^{111}$ But in no newspaper was Cassidy the leading item from the assizes. Each gave the case just a few lines on the third or fourth page, and went with a long, detailed report about a murder in Carrickmacross as their main story. Other sexual crimes, like heterosexual rape or paedophilia, were often relayed more openly, but homosexuality was a topic mostly ignored to publicly downplay its extent. ${ }^{112}$ The only exception to this rule was when a same-sex crime occurred in England; nationalist newspapers especially, who were politically motivated to stress English degeneracy in comparison to Irish purity, were then much happier to provide details. ${ }^{13}$

The reluctance to name home-grown homosexuality likely meant any public shame that came with conviction did not have to remain forever attached to the accused; life went on and was facilitated by Ulster kinship networks. After Cassidy was released, he moved to Moneymore, a village not far from his Ardboe family. If his past was known, locals seemingly did not care; they remembered him in 1930 as a popular 'gentleman of independent means', though not the sort of figure they were 'accustomed to' given his 'certain amount of mystery'. ${ }^{114}$ That they were moved to comment on Cassidy at all was only because of his remarkable reappearance in the press, not in the News Letter, but the Daily Mirror and Daily Mail. ${ }^{115}$ Cassidy had become engaged to a minor aristocrat, Lady Rosemary Bootle-Wilbraham, when a 'love affair' from some five years previous was rekindled after they 'met again casually' at a London party. Bootle-Wilbraham, daughter of the earl of Lathom, had been engaged twice already: first to Richard Cosmo Alderson, son of Sir Edward Alderson; and second to James Watts, owner of Abney Hall in Cheshire. ${ }^{116}$ Cassidy's charms must have been substantial. He had reinvented himself as a man in the 'film industry', wooed a woman far above his social class and even persuaded her to convert to Catholicism (the Holy Communion at the nuptial mass was apparently her first). ${ }^{117}$ In Armagh, where his father still lived, the local Standard reported a 'sensation', ${ }^{118}$ and in Moneymore, the Mid-Ulster Mail hinted suggestively that 'few expected that he would end his bachelor career as the son-in-law of an earl!"119 Just ten months later Cassidy fell ill while having a bath in their Kensington home. His death of a brain aneurism at just forty years old made the front page of the Daily

111 Belfast News Letter, 11 Dec. 1917.

112 See, as an example, the report about James Connolly's 'improper behaviour' toward young girls, including details about the neighbourhood, prevalence of the offence and the 'little girls' who gave evidence: Belfast News Letter, 9 Apr. 1913.

${ }^{113}$ As an illustration of the heavier detail given to queer cases in England see the report on a clerical scandal in Irish News and Belfast Morning News, 3 Nov. 1905. For context, see Earls, 'Unnatural offenses of English import'.

${ }_{114}$ Mid-Ulster Mail, 2 Aug. 1930.

115 Daily Mirror, 24 July 1930; Daily Mail, 24 July 1930.

116 Leeds Mercury, 28 July 1930.

117 The Advocate, 25 Sept. 1930.

118 Ulster Gazette and Armagh Standard, 23 May 1931.

${ }^{119}$ Mid-Ulster Mail, 2 Aug. 1930. 
Express. $^{120}$ Cassidy's father and many brothers, as The Times reported, journeyed to London to join his widow for the requiem mass at the Church of Our Lady of Victories in Kensington, before he was buried at St Mary's in Kensal Green. ${ }^{121}$ Cassidy's conviction had thus not been the end of his social or family life. For those with the will and ability, it was possible to either reintegrate into Irish society or climb the social ladder beyond. ${ }^{122}$ For Sheehan and Kavanagh, life also went on, but with some suggestive differences. Sheehan did not return to his medical studies at Queen's, possibly the taint of scandal being too much for the administration. ${ }^{123}$ Nevertheless, his family did not disown him and he went to work in the family spirit grocers. In 1923, he married a local woman, Kathleen McKinney, before emigrating to the U.S.A. in $1930 .{ }^{124}$ Francis Kavanagh had done the same. By 1925 he was working as an athletic trainer in Canton, New York, and married to an American. ${ }^{125}$ A youthful queer experience could be part of a life-cycle that still ended in marriage, the 'dominant indicator of social inclusion' for 'men to be considered fully masculine', even if possibly a result of heteronormative duty and not desire. ${ }^{126}$

Milligen, however, does seem to have suffered. When arrested, he apparently asked 'Is there any possible way out of this? If it is made public I will be ruined., 127 Though legally innocent and unnamed in the press, his social standing must surely have meant that word got around. Still, by 1921 he had set up a new coal-selling business with his father, though the latter, perhaps for suggestive reasons that are impossible to confirm, chose in 1919 to sell his house and leave the village. ${ }^{128}$ Certainly, there were no more reports about the technically-innocent Edgar undertaking public charitable roles or working with the youth of Lambeg. His family does not seem to have cut him off financially, however. In 1930, for example, he was travelling by steamship (first-class) from London to Port Said and intending to stay in then-Ceylon for at least a year, yet he listed himself as being without a profession. ${ }^{129}$ He never married, and died of various lung and heart conditions in 1939 at the age of fifty-two, and, according to his death certificate, still living off his 'independent means'. His last address was about a mile north of the friends that had provided his sureties, Slievemoyne Park, a stretch of the Antrim Road with large detached houses (though nowhere near as grand as Glenmore House where he

120 Daily Express, 20 May 1931; Mid-Ulster Mail, 23 May 1931.

121 The Times, 23 May 1931.

122 Cassidy's move from Irish queer ex-con to London high society is redolent of the creative 'remaking' that marked interwar society, untangled expertly in Matt Houlbrook, Prince of tricksters: the incredible true story of Netley Lucas, gentleman crook (Chicago, 2016).

123 'Hugh P. Sheehan, Faculty of Medicine, Queen's University Belfast', matriculation records (Queen's University Belfast student records).

${ }^{124}$ Marriage between Hugh P. Sheehan and Rachel McKinney, 25 Jan. 1923 (General Register Office for Northern Ireland [hereafter G.R.O.N.I.], registration number: M/1923/ B1/2333/12/155); Adriatic leaving Belfast, 20 Sept. 1930 (T.N.A., Board of Trade: Commercial and Statistical Department and successors: outwards passenger lists, BT27).

${ }_{125}$ Marriage between Francis Kavanagh and Pauline Ruth Mahon, 23 Apr. 1925, registration number: 11925, in 'Record of Marriages 10501-11500' (1923-5), St Lawrence County, New York.

${ }^{126}$ Brady, Masculinity and male homosexuality in Britain, p. 47.

127 'Edgar Milligen - gross indecency'.

128 Belfast News Letter, 4 Aug. 1921; Belfast News Letter, 13 June 1919.

129 Kaiser-I-Hind leaving London, 21 Nov. 1930 (T.N.A., Board of Trade: Commercial and Statistical Department and successors: outwards passenger lists, BT27). 
grew up). ${ }^{130}$ Present at the death was Richard Milligen Harcourt, his cousin through his father's sister and a notable local figure (former city councillor and High Sheriff, and director of F.E. Harcourt and Co.). In the decades after, other members of the Milligen family went on to bigger things in the province, most famously, Sir Robert John Rolston Harcourt, who was a unionist M.P. and Belfast lord mayor. Edgar Milligen, however, received no glowing obituary, just a brief notice of a 'private' funeral. ${ }^{131}$

Class, religious and political power, and discourses of respectability all intersected with the experience of and response to same-sex relations. Milligen's social status in Ulster meant that he was better prepared to navigate the legal system, whereas Cassidy faced a much tougher fight. But, conversely, the civically active son of a major industrialist had further to fall publicly than an unknown saddler's boy. In light of this, Milligen's clandestine approach to sexual cruising in contrast to Cassidy's seemingly clearer embracing of queerness begins to make more sense, as does the former's disappearance from public life while the latter audaciously entered London's high society.

In this article I have tried to show how the Irish city was actually experienced by queer men in the early twentieth century. Street culture provided opportunities for coded displays that led to sexual encounters, whether in public places or behind closed doors. Pubs and hotels could be ambiguous enough for men to pick up each other or continue relationships out, to a large degree, in the open. Different power dynamics, motives and identities were apparent in the diversity of same-sex relations: working-class lads, otherwise 'heterosexual', supplementing their meagre incomes by satiating the desires of older wealthier men; one-off trysts between men of the same and also different classes; and longer-term homosocial relationships as much about friendship and fun as sexual satisfaction. The potential for prosecution existed, but the risk was low; only a tiny number of men were arrested and, of the seven men from these two cases that admitted to sexual relations with other men, only one was imprisoned. Some expressed shame or remorse about their actions, especially when caught by the police, but others were honest or even accepting of their desires. To have a same-sex interaction was not necessarily to view oneself as abnormal.

Belfast, unsurprisingly, was not London or New York in the scale or visibility of the queer lives it housed. But it shared a similar geographic, spatial and social composition that 'shaped' and 'sustained' modern 'male sexual practices and identities'. ${ }^{132}$ As I have argued, however, there were also idiosyncrasies. Men moved across multiple Irish worlds, from rural homes and communities to ports and global cities. In doing so, they did not just carry ideas and understandings of masculinity and sexual openness to other places but brought them back too. The First World War contributed to this culture by further enabling both male movement across Britain and Ireland and the homosocial environments where sexual relationships could

${ }^{130}$ Edgar Milligen death registration, 17 Jan. 1939 (G.R.O.N.I., registration number: D/ 1939/48/1007/104/54).

131 Belfast News Letter, 18 Jan. 1939.

132 Houlbrook, Queer London, pp 3-4. 
happen. The war, however, was more of a catalyst than a cause; arrests for same-sex offences, after all, both predated and continued after the conflict. Probably its most notable effect, then, was creating the conditions of moral panic that forced the authorities to bring into plain view a (sub)culture that already existed. After arrests were consequently made, the same Irish networks that had enabled queer men also provided bail money, facilitated the continuance of a semblance of the accused's former life or enabled their move to a new one. If a moment in court arrived, individual fates were determined not just by transnational notions of respectability and masculinity but also the distinctive circumstances of Ulster. Religious and political affiliation, and the intersection of that identity with civic and political power, could have converse effects. Awell-known Ulster Protestant like Milligen could get off on a charge of gross indecency yet find his public life over, while an unknown Catholic like Cassidy stood little chance in court but managed to prosper afterwards.

To think more about same-sex desire in terms of diasporic networks, urban-rural connections and religiously-inflected power structures helps nuance the political (and often politicised) approaches to Ireland's queer history. But it also contributes more broadly to the methodology of the history of sexuality. Ireland's example, as suggested by this case study of Belfast, provides evidence of both a 'regional' queer experience and 'the insufficiency' of an approach that 'begins and ends at the city limits' ${ }^{133}$ Historians of Ireland could take this approach even further by charting the development of queer cultures beyond the period of revolution, war and partition. The relative strength of religious institutions in both developing states - a strength that was still evident when the gay rights movement started to gather steam internationally in the late 1960 s - is well-recognised in the historiography. Less understood though, and especially in the case of the six counties that became Northern Ireland, is how these political cultures shaped the actual experiences and identities of everyday queer people before the liberationist crusade. ${ }^{134}$ To re-orientate away from campaigns and towards urban culture on the ground might thus reveal new and deeper insights into how Irish and Northern Irish societies confronted or accommodated queer relationships long before the struggle to make same-sex desire equal before the law. ${ }^{135}$

${ }^{133}$ Helen Smith, 'Working-class ideas and experiences of sexuality in twentieth-century Britain: regionalism as a category of analysis' in Twentieth Century British History, xxix, no. 1 (2018), pp 58-78, and, for quotation, Claire Potter, 'A queer public sphere: urban history's sexual landscape' in Journal of Urban History, xl, no. 4 (2014), p. 813.

${ }^{134}$ Averill Earls, 'Queering Dublin', has taken up this gauntlet for the capital but other parts of the pre-1970s Republic still await attention.

${ }^{135}$ My thanks go to Yassin Brunger, Richard Butler, Sean Connolly, Jeff Dudgeon, Darragh Gannon, Alison Garden, Sarah Jankowitz, Michael Lawrence, Daryl Leeworthy and Keira Williams for their incisive comments on earlier drafts of this article, and to Richard O'Leary and Graham Walker for many illuminating conversations about Belfast's queer history. 